\title{
KRETUONAS: CUT-MARKS ON HUMAN BONES AND THEIR IMPLICATIONS FOR THE BURIAL TRADITIONS OF EARLY-MIDDLE NEOLITHIC COMMUNITIES IN LITHUANIA
}

\author{
MANTAS DAUBARAS
}

Vilnius University, Universiteto St 7, Vilnius, Lithuania

\section{Keywords}

Kretuonas, cut-marks, bioarchaeology,

Neolithic,

burial traditions
Abstract

This paper presents new bioarchaeological data obtained during the re-analysis of human skeletal materials from the Early-Middle Neolithic Kretuonas 1 graves, excavated in 1980. The re-analysis of 6 inhumation burials revealed the earliest-known cases from Lithuanian archaeological material to show signs of perimortem cut-marks left on human bones. An evaluation of the first cases of perimortem human bone cut-marks in the broader European archaeological context allowed us to argue that different burial practices existed in Early-Middle Neolithic communities in the present territory of Lithuania. What is more, we argue that different people received different mortuary practices, and that their cadavers were handled in distinct ways.

\section{Introduction}

The burial traditions of past societies are among the most widely researched themes in archaeology, as the evolution of these traditions can tell us a lot about the conflicts and diseases that certain societies had to live through, and show economic and social changes. A lot of research has been done on Stone Age burial traditions in the Baltic Sea region. Pioneering research into the practices in burial traditions, as opposed to the analysis of burials themselves (i.e. the number of grave goods, biological sex and age of the deceased, etc), of Stone Age Baltic Sea communities was carried out by Liv Nilsson Stutz (2003). Nilsson Stutz was the first to implement archaeothanatology in studies of the burial traditions of Stone Age Baltic Sea communities, and later even contemplated the idea of the 'Baltic Way of Death' (Nilsson Stutz 2010). The research done by

\footnotetext{
* E-mail: mantas.daubaras@gmail.com
}

Nilsson Stutz quickly attracted attention, and the re-analysis of human skeletal remains from old excavations began. Professional bioarchaeologists published fundamental works concerning the burial traditions of Stone Age societies in Latvia (Nilsson Stutz et al., 2013), Sweden (Nilsson Stutz 2010; Fahlander 2010) and Estonia (Tõrv 2016). These authors showed that the bodies of people who died in the Baltic Sea region during the Stone Age were not all treated in the same way. Some burials were re-opened, and certain body parts were removed after the decomposition of soft tissues occurred. Skeletal elements were shown to bear signs of cut-marks, suggesting that parts of the bodies were removed from the corpses following death. 


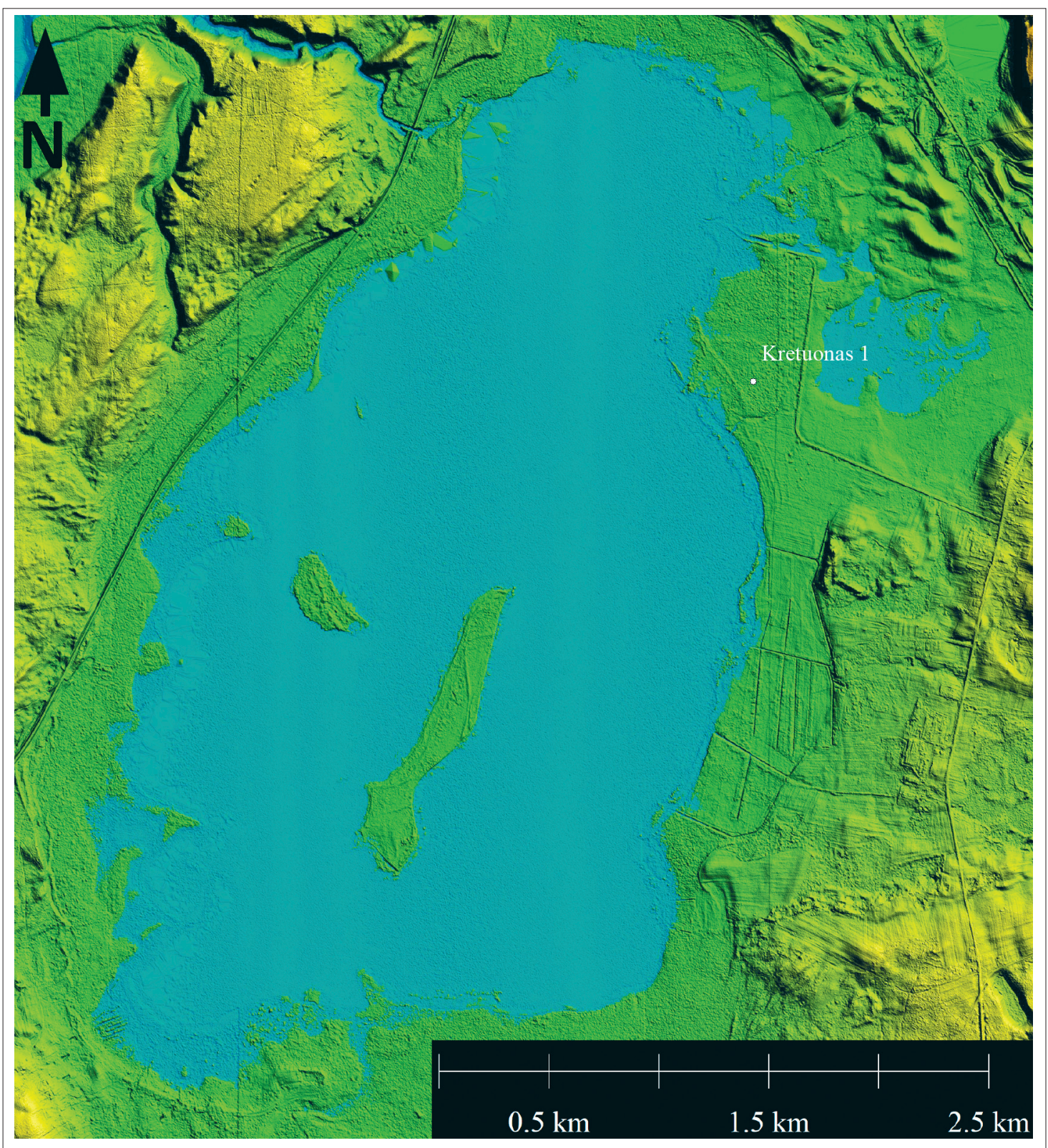

Figure 1. The situation of the Kretuonas 1B archaeological site. LiDAR based map (drawing by the author).

In Lithuanian archaeology, however, no attention has been paid to the burial traditions of Stone Age communities. Typically, only descriptions of burials themselves are given (Rimantiene 1996; Girininkas 2009), with one attempt made by A. Butrimas, where he came up with the groundless argument that a woman was sacrificed and buried together with a 'soothsayer' in Donkalnis cemetery (Butrimas 2012; Girininkas 2013).

This paper is the first attempt to analyse aspects of the burial traditions of Early-Middle Neolithic communities in the present territory of Lithuania that have not previously been discussed in archaeological literature. By revisiting human skeletal remains from Kretuonas cemetery, we analyse why we think different burial practices existed in Early-Middle Neolithic communities in the present ter- ritory of Lithuania, and corpses of different people were treated in distinct ways. The results of these investigations present an opportunity to further investigate the variability of burial traditions.

\section{Materials and methods}

Archaeological sites situated around Lake Kretuonas in northeast Lithuania are among the best-known Stone Age localities in the east Baltic, because of extensive excavations that have yielded sites with the perfect preservation of archaeological finds (Girininkas et al., 1985; Girininkas 1990; Brazaitis 2002a). More than 25 Stone Age and Bronze Age sites were discovered on the shores and islands of Lake Kretuonas and Žemaitiškè, or on the 


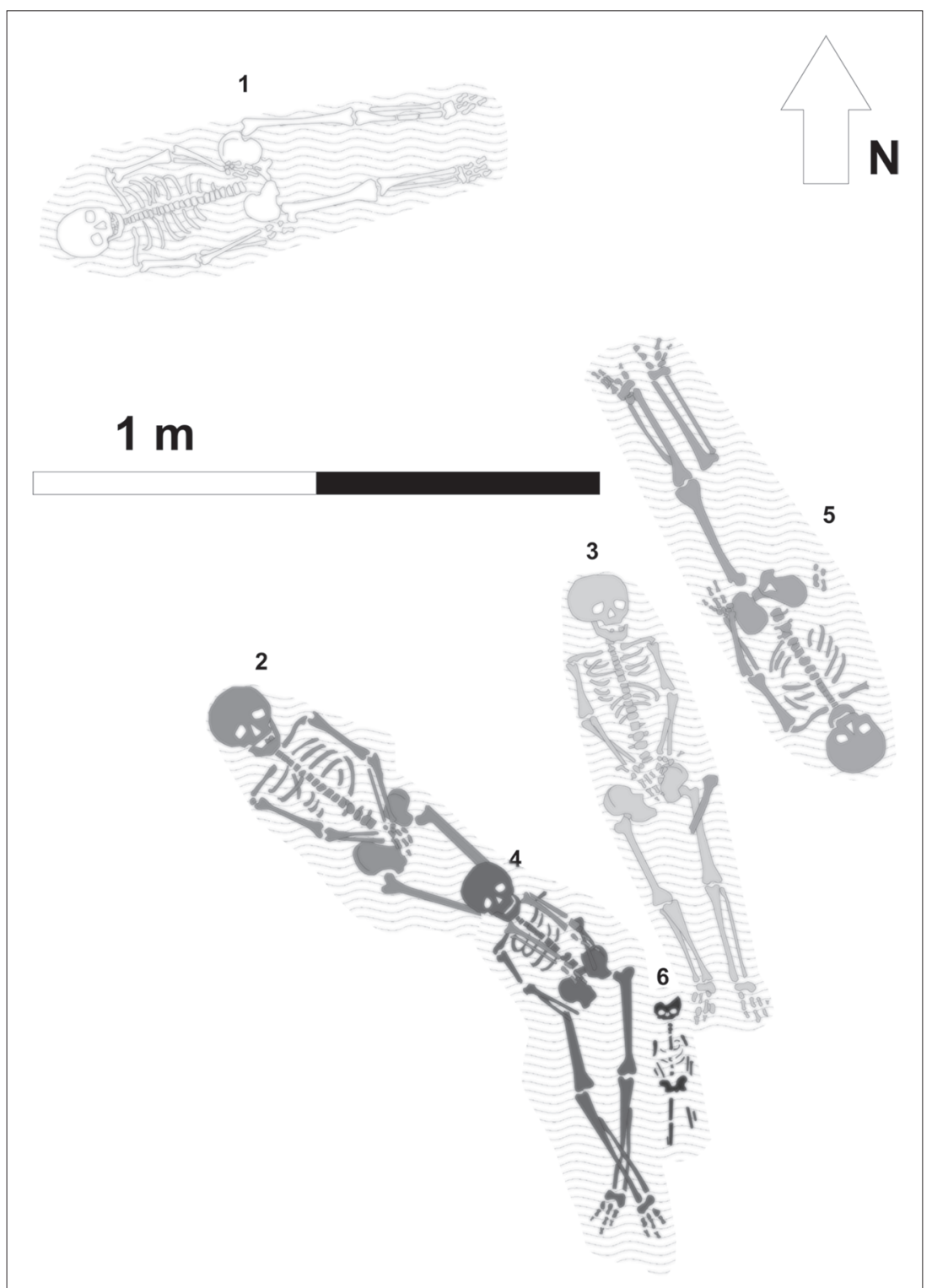

Figure 2. A general view of the Kretuonas burials and their numbers (modified and re-drawn by the author, after Girininkas, 1985).

bed of the ancient rivulet connecting them. Most have a very broad chronology, ranging from the Early Neolithic (5500/5300-4400/4200 cal BC) to the Early Bronze Age (2100/2000-1750 cal BC), and the different pottery found at these sites has been classified as Narva, Comb Ware, Globular Amphora and Corded Ware cultures. In 1980, 6 inhumation burials dated to the Early and Middle Neolithic periods were discovered at the Kretuonas 1 site. It lies on a sandy hillock, with Lake Kretuonas to the west, and a small rivulet to the south (Fig. 1).

The site was first discovered in 1978, when the area was ploughed. Ploughing resulted in the major disturbance of cultural layers, so a clear stratigraphy was only partially preserved. Inhumation burials, however, avoided disturbance and were found in situ (Fig. 2).
An initial report on the burials appeared in 1985, but after repeated investigations carried out in 2019, it became clear that some specific features of the anthropological materials had previously gone unnoticed. It became apparent that the newly discovered anthropological features had great potential to contribute to a better understanding of the burial rituals during the Early-Middle Neolithic. Firstly, skeletal remains were properly cleaned with a dry brush to get a good view of the materials. Secondly, a low magnification visual inspection was carried out. Six individuals were analysed. The sex and age of the individuals was assessed using standard osteological techniques (Buikstra and Ubelaker 1994). The age at death in adults was estimated using morphological changes in the pubic symphyses and cranial suture closure. The skeletons themselves are stored in the repository of Vilnius University. 


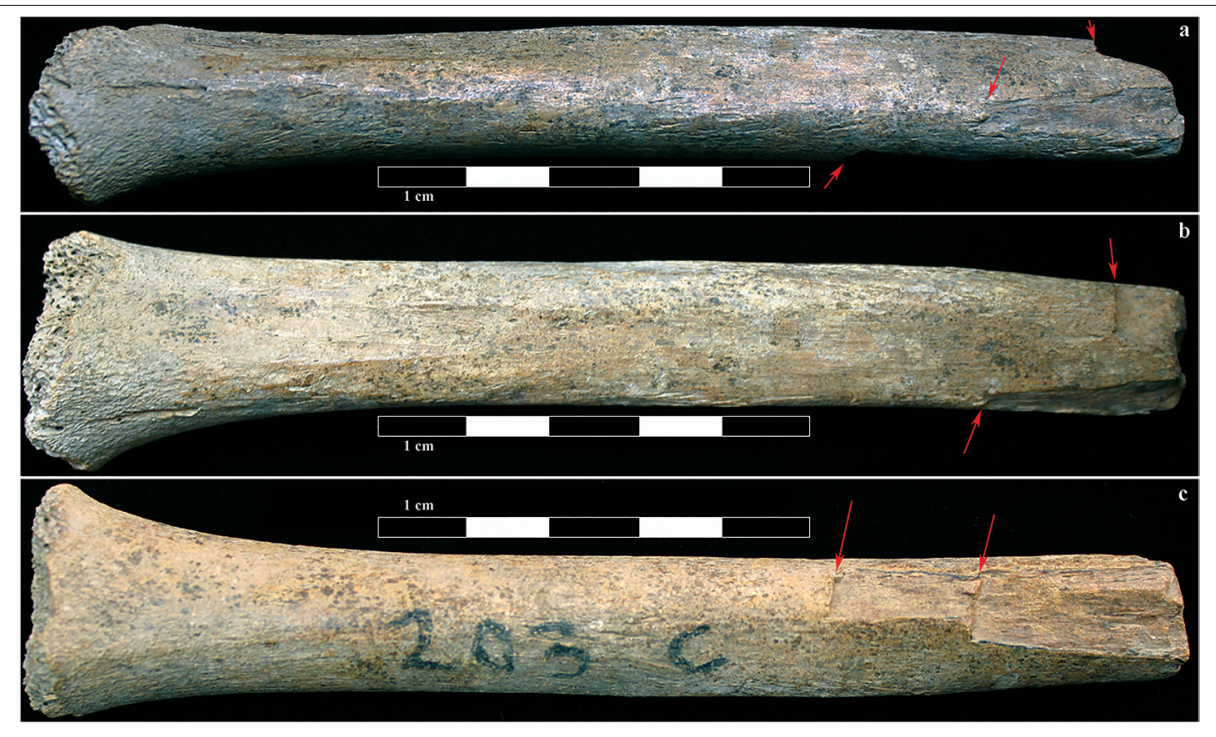

Figure 3. Views of the left humerus, with arrows showing the cut marks (a. medial view; b. anterior view; c. lateral view) (photograph by the author).

\section{Results}

Low magnification visual inspection revealed intentional and repetitive cases of perimortem cut-marks on the left humerus (Figs. 3 ; 4) and the right femur (Figs. 5; 6) of individual from grave 2 (postcranial No 203C).

The individual from grave 2 was a 14 to 16 -year-old adolescent of unknown sex. The left humerus had 4 separate cuts, the right femur had 3 cuts. The cuts were made with a fine sharp-edged tool. Their positioning allowed us to determine that the diaphysis of the bones were cut along their longitudinal axis first, and then broken transversely. These are not the type of cut-marks that are usually associated with bone splitting for marrow extraction (Kooyman 2004, Outram 2001). This is currently the only known case from Lithuanian prehistory of a human bone with cut-marks.

\section{Discussion}

The discovery of intentional and repetitive perimortem cut-marks on human bones enables us to state that different burial practices existed in Early-Middle Neolithic communities in the present territory of Lithuania. Different people received different mortuary practices, and their bodies were handled in distinct ways.

Some researchers have argued that people who migrated from other communities might have been buried in different ways. We can look at individuals' life stories from different points of view, but the genetics, diet and chronology of a buried individual could be the most telling. The individual from grave 2 was genetically similar to other individuals from burials in Kretuonas. The male individuals of the community carry Y-chromosomal haplogroup of the I clade (i.e. I2a1b), and the maternal lineage carry mtDNA genomes from Holocene Scandinavian and West European hunter-gatherers (i.e. U5) (Mittnik et al., 2018, p. 6).

Previous attempts to establish the absolute chronology of grave 2 were unsuccessful (Piličiauskas et al., 2017, p. 533), but a sufficient yield in genetic data showed individuals from graves 2 and 5 to be identical twins (Mittnik et al., 2018 , p. 9). Grave 5 was interred with a 25 to 30 -year-old male who was directly AMS dated to 4450-4340 cal BC (5540+/-35 Poz-64677). With a known age at death of both individuals from graves 2 and 5, it is calculated that grave 2 is roughly 10 to 15 years older than grave 5 . This calculation places it somewhere in the middle of the 5 th millennium BC or the end of the Early Neolithic (Antanaitis-Jacobs and Girininkas 2002), although all absolute dates from Kretuonas can be subjected to offsets caused by freshwater reservoir effect (FRE). The level of FRE remains uncertain due to the limited work to date (Piličiauskas and Heron 2015, p. 543).

The stable isotope analysis of Kretuonas materials was attempted previously (Antanaitis and Ogrinc 2000; Piličiauskas et al., 2017). Unfortunately, the insufficient preservation of bone collagen or unreliable oxygen and nitrogen ratios (DeNiro 1987) impeded the results. With this level of preservation, it is hard to identify the life story (i.e. migrations during their lifetime) of each individual. The data that we have, however, enables us to see that individuals from Kretuonas fall into the general cluster of inland hunters-fishers, with a mixed diet of freshwater food 

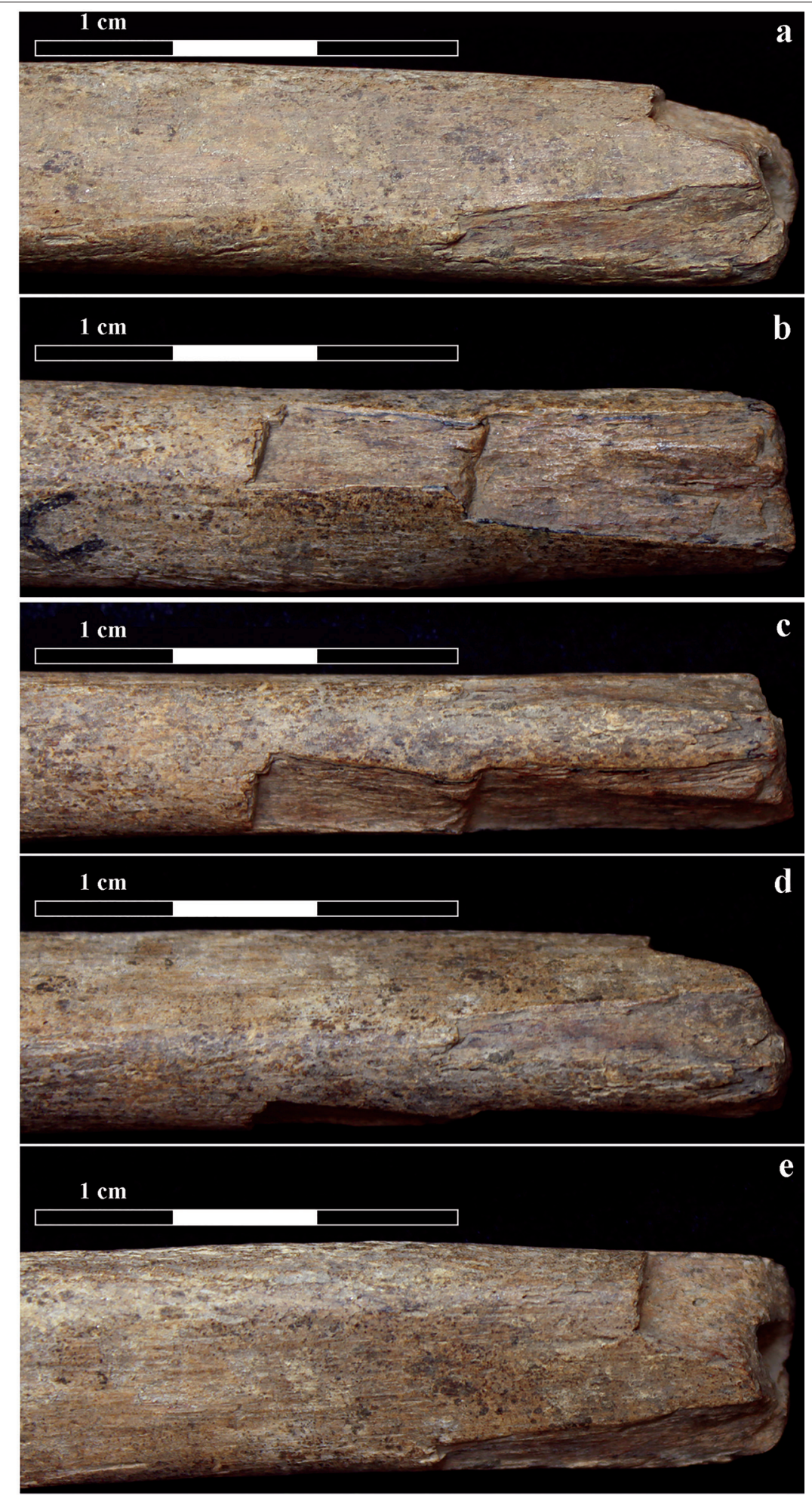

Figure 4. Close-up views of the cut marks on the left humerus (a. anteromedial view; b. lateral view; c. laterodorsal view; d. medial view; e. anterior view) (photograph by the author). 


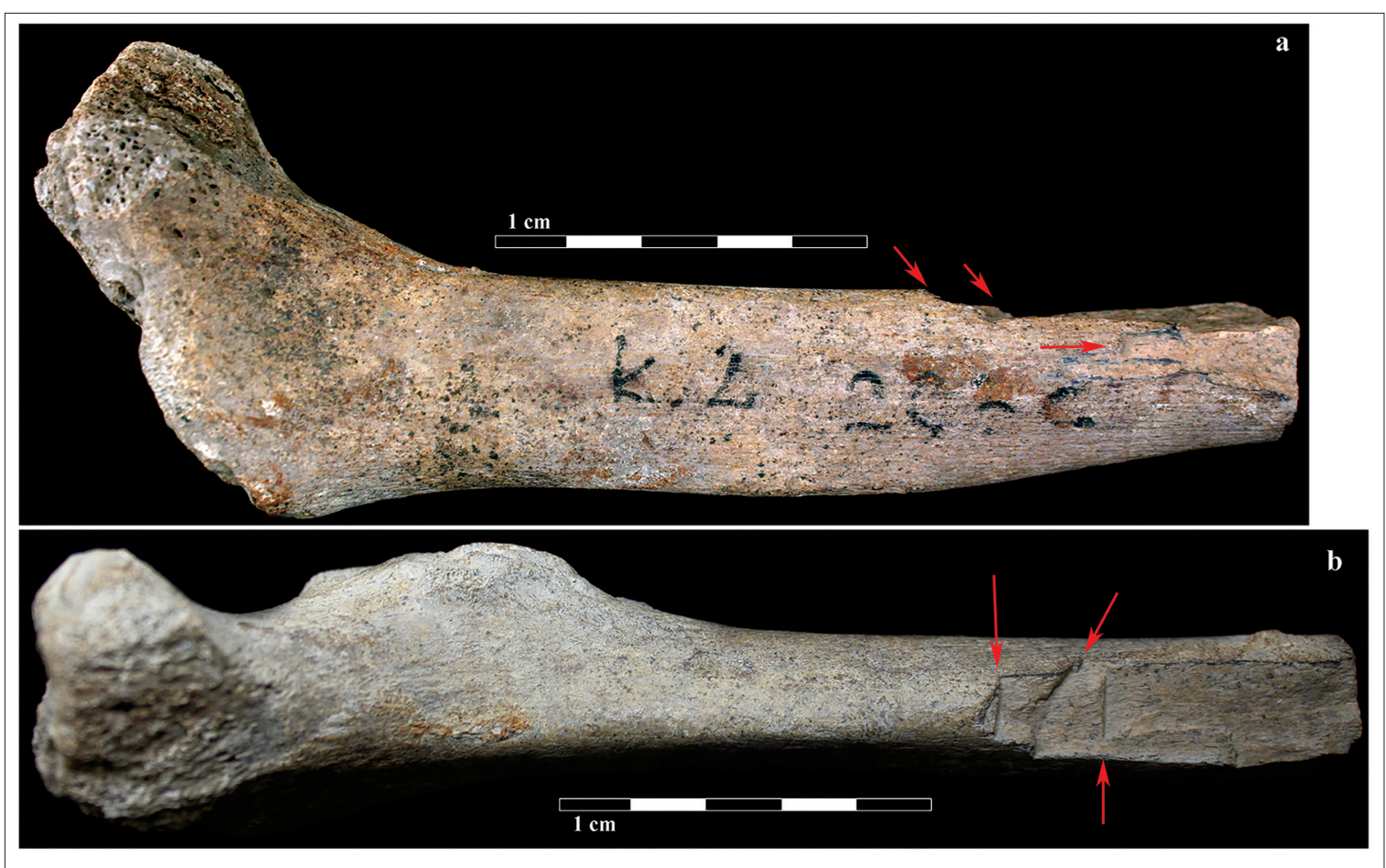

Figure 5. Views of the right femur, with arrows showing the cut marks (a. anterior view; b. medial view) (photograph by the author).

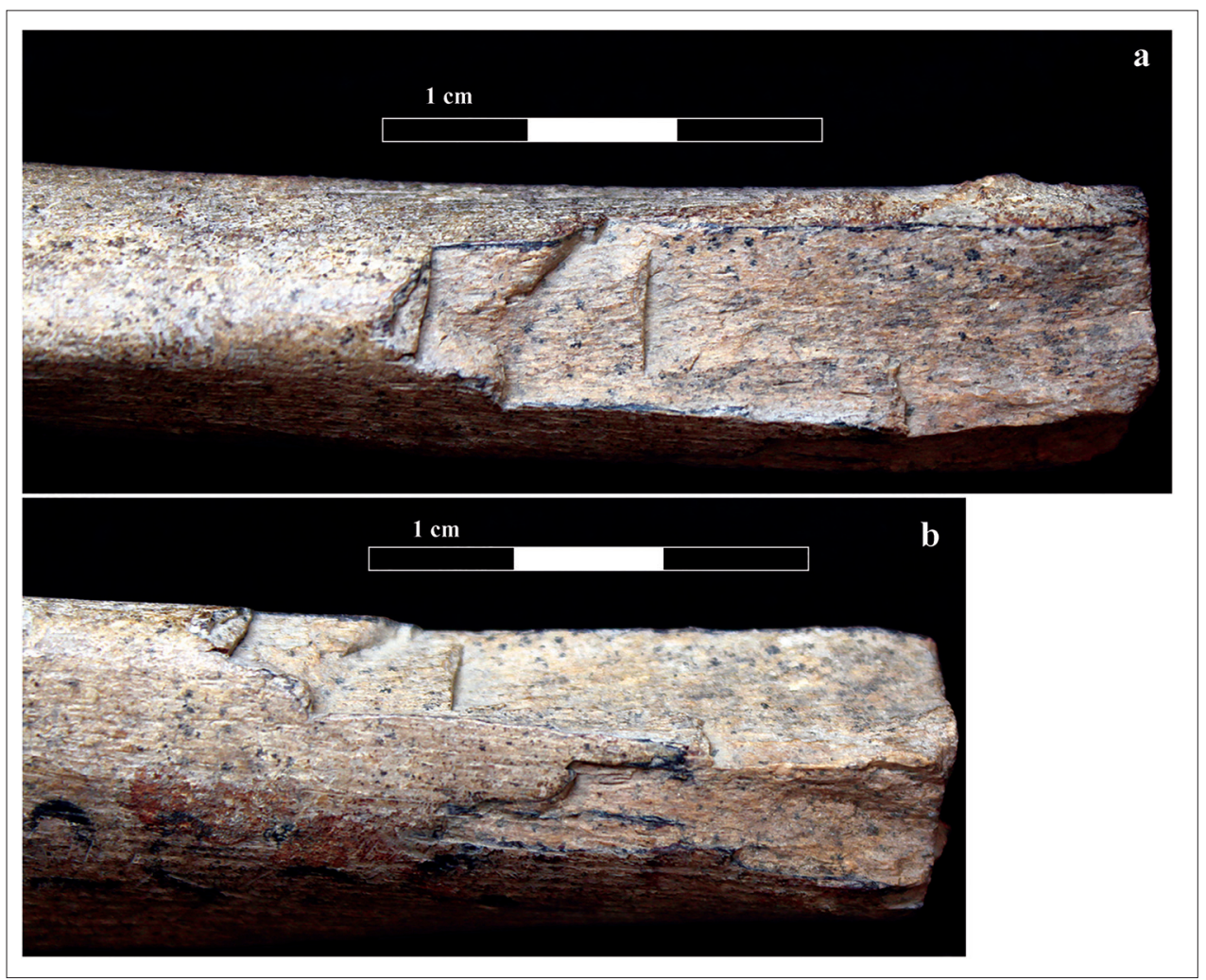

Figure 6. Close-up views of the cut marks on the right femur (a. medial view; b. anteromedial view) (photograph by the author). 
and hunted forest animals, and with a substantial amount of foraged plant food (Piličiauskas et al., 2017).

All the above-mentioned results show that the individuals from Kretuonas cemetery were locals; all of them could be traced back genetically to autochthons of post-glacial Europe. Stable isotope analysis, although limited, shows no deviation from the general east Baltic inland hunterfisher diet observed in neighbouring areas (Eriksson et al., 2003; Tõrv 2016, pp. 197-211). The chronology of the burials also falls within a short period of time, and shows that this cemetery was probably used for several dozen to several hundred years during the period 4500-4300 cal $\mathrm{BC}$, and its short usage appears to be the exception rather than the rule for Stone Age cemeteries in the east Baltic (Piličiauskas et al., 2017, p. 534).

The question arises, why was a person of local origin, the same diet and the same chronology buried in a distinct way, and why do parts of his skeleton have cut-marks?

Cases of human bones with cut-marks from the Stone Age have been observed in numerous sites throughout Europe. The earliest cases are found in the Palaeolithic bone assemblages from Gough's Cave in England (Bello et al., 2011). Numerous cases are recorded in Mesolithic sites at Kent's Cavern, Grotte des Perrats, Noyen-sur-Seine, Hardinxveld, and Drigge, to name but a few (Jones 2011, pp. 229, 231, 233, 240). The Neolithic period saw a major change in burial practices brought in by farming communities. The East Baltic region, however, remained on the fringes of the newly emerging farming world for a considerably longer time, and hunter-gatherer burial traditions persisted well into the Neolithic period (Nilsson Stutz 2010, p. 141). A change in burial traditions in the east Baltic can only be seen in the middle of the 3rd millennium BC (Tõrv 2016, p. 324), and can be associated with the spread of Corded Ware culture. The geographically and chronologically closest analogy to the Kretuonas case was found in the Narva Joaorg I burial in Estonia (Tõrv 2016, p. 215). Other researchers have pointed out that cut-marks show the fact that cadavers of particular individuals were manipulated after death, and certain parts of their bodies were cut off as part of the burial ritual (Nilsson Stutz 2003; Jones 2011; Tõrv 2016). Some researchers have taken their interpretations a step further, and stated that loose human bones, occasionally found in Stone Age occupation layers, are fragments of once removed cadaver parts (Sørensen 2016). Cut-marks found on the individual from Kretuonas are interpreted as a sign of the removal of a certain part of its body, leaving cut-marks while doing so. It is noteworthy that the occupation layer of the Kretuonas 1 site had a considerable amount of loose human bones (Girininkas 2008), which might either have come from disturbed burials (Girininkas 1998; Brazaitis 2002b), or be the remnants of once ritualistically used cadaver parts that were later disposed of, as is seen in other European sites (e.g. Sørensen 2016). The abundance of cases with cut-marks in European Stone Age material shows that different burial practices existed simultaneously in each archaeological period of the Stone Age. With the first case of cut-marks in Lithuania, we see that this can be said about the EarlyMiddle Neolithic communities that once lived here. The works of other researchers support this notion.

\section{Conclusions}

Cases of cut-marks on human bones were discovered after the re-analysis of skeletal remains from Kretuonas EarlyMiddle Neolithic (5500/5300-3100/2900 cal BC) graves. These are the first such cases found in Stone Age sites in the present territory of Lithuania.

The discovery of cut-marks on human bones allows us to prove that Early-Middle Neolithic communities in the present territory of Lithuania belonged to a wider European circle of hunter-fisher communities, where different burial practices with different people receiving different mortuary practices, and their bodies being handled in distinct ways, is an established fact (Nilsson Stutz 2003; Jones 2011; Tõrv 2016).

To advance the understanding of Stone Age burial traditions in the east Baltic further, a complete re-analysis of the anthropological material from old excavations has to be done. This material may be informative, and may reveal new details that were previously overlooked. What is more, the paradigm of burial archaeology in the east Baltic always focused on the graves (i.e. the biological attributes of the deceased, the number and type of grave goods, etc), rather than the burial practices. With a changed point of view, and a more holistic and scientific approach to the graves, new insights into the burial traditions may emerge, especially bearing in mind the treasure trove archaeological collection of Stone Age sites at the Zvejnieki and Olenii Ostrov burial sites, the Lake Lubana area, the Kryvina peat-bog site, the Serteya site, etc.

\section{Acknowledgments}

The author is grateful to Rimantas Jankauskas for granting access to the repository of Vilnius University, and to Justina Kozakaite for her valuable insights.

\section{Abbreviations}

Arch. Baltica - Archaeologia Baltica

Lietuvos Arch. - Lietuvos archeologija 


\section{References}

Antanaitis, I. and Ogrinc, N., 2000. Chemical analysis of bone: stable isotope evidence of the diet of Neolithic and Bronze Age people in Lithuania. Istorija, 45, 3-12.

Antanaitis-Jacobs, I. and Girininkas, A., 2002. Periodization and Chronology of the Neolithic in Lithuania. Arch. Baltica, $5,9-39$.

Bello, S.M., Parfitt, S.A. and Stringer, C.B., 2011. Earliest Directly-Dated Human Skull-Cups. PLoS One, 6(2), e17026, https:// doi.org/10.1371/journal.pone.0017026.

Brazaitis Dž., 2002a. Rytu Lietuva neolito ir bronzos amžiaus sandūroje. Thesis (PhD), Lietuvos Istorijos institutas, Vytauto Didžiojo universitetas.

Brazaitis, Dž., 2002b. Rutulinių amforų kultūra Lietuvoje - reiškinys ar epizodas? Lietuvos Arch., 23, 29-40.

Buikstra, J.E., Ubelaker, D.H. and 1994. Standards for data Collection from Human Skeletal Remains: Proceedings of a Seminar at the Field Museum of Natural History, organized by Jonathan Haas. Arkansas Archaeological Survey Research Series, 44, 16-21.

Butrimas, A., 2012. Donkalnio ir Spigino mezolito-neolito kapinynai. Seniausi laidojimo paminklai Lietuvoje. Vilnius: Vilniaus dailès akademijos leidykla.

DeNiro, M.J., 1987. Stable isotopy and archaeology. American Journal of Science, 75, 182-191.

Eriksson, G., Lõugas, L. and Zagorska, I., 2003. Stone Age hunter-fisher-gatherers at Zvejnieki, northern Latvia: radiocarbon, stable isotope and archaeozoology data. Before Farming, 1 (2), 1-25, https://doi.org/10.3828/bfarm.2003.1.2.

Fahlander, F., 2010. Messing with the dead: post-depositional manipulations of burials and bodies in the South Scandinavian Stone Age. Documenta Praehistorica, 37, 23-31, https:// doi.org/10.4312/dp.37.2.

Girininkas, A., 1998. Kapas urnoje. Lietuvos Arch., 15, 133-136.

Girininkas, A., 1990. Kretuonas. Vidurinis ir velyvasis neolitas. Lietuvos Arch., 7. Vilnius: Mokslas.

Girininkas, A., 2008. Neolitas. In: A. Girininkas, ed. Lietuvos istorija. I tomas: Akmens amžius ir ankstyvasis metaly laikotarpis. Vilnius: Baltos lankos, 103-187.

Girininkas, A., 2009. Akmens amžius. Lietuvos archeologija, 1. Klaipeda: Versus Aureus.

Girininkas, A., 2013. Stone Age Dating issues: in 'Donkalnis and Spiginas Mesolithic- Neolithic Cemeteries: The Oldest Burial Sites in Lithuania' (Donkalnio ir Spigino mezolito-neolito kapinynai. Seniausi laidojimo paminklai Lietuvoje) by A. Butrimas (Vilnius, 2012); and ' $\mathrm{New}{ }^{14} \mathrm{C}$ Dates of Neolithic and Early Metal Period Ceramics in Lithuania' by G. Piličiauskas, M. Lavento, M. Oinonen and G. Grižas, In Radiocarbon (2011, Vol. 53/4). Arch. Baltica, 20, 206-207.

Girininkas, A., Česnys, G., Balčiūnienè and I., Jankauskas, R., 1985. Kretuono I-os gyvenvietès vidurinio neolito kapai. $L i$ etuvos Arch., 4, 5-14.

Jones, A.G., 2011. Dealing with the Dead: Manipulation of the Body in the Mortuary Practices of Mesolithic North West Europe. Thesis (PhD), University of Manchester.

Mittnik, A., Wang, C., Pfrengle, S., Daubaras, M., Zarina, G., Hallgren, F., Almäe, R., Khartanovich, V., Moiseyev, V., Tõrv, M., Furtwängler, A., Valtueña, A., Feldman, M., Economou, C., Oinonen, M., Vasks, A., Balanovska, E., Reich, D., Jankauskas, R., Haak, W., Schiffels, S. and Krause, J., 2018. The genetic prehistory of the Baltic Sea region. Nature Communications, 9 (442), 1-11, https://doi.org/10.1038/s41467-018-02825-9.

Nilsson Stutz, L., 2010. The way we bury our dead. Reflections on mortuary ritual, community and identity at the time of the
Mesolithic-Neolithic transition. Documenta Praehistorica, 37, 33-42, https://doi.org/10.4312/dp.37.3.

Nilsson Stutz, L., Larsson, L. and Zagorska, I., 2013. The persistent presence of the dead: recent excavations at the huntergatherer cemetery at Zvejnieki (Latvia). Antiquity, 87 (338), 1016-1029, https://doi.org/10.1017/S0003598X00049838.

Nilsson Stutz, L., 2003. Embodied Rituals and Ritualized Bodies. Tracing ritual practices in late Mesolithic burials. In: Acta Archaeologica Lundensia, 46. Stockholm: Almqvist \& Wiksell International.

Nilsson Stutz, L., 2010. A Baltic Way of Death? A Tentative Exploration of Identity in Mesolithic Cemetery Practices. In: A.M. Larsson and L. Papmehl-Dufay, eds. Uniting Sea II. Stone Age Societies in the Baltic Sea Region. Borgholm: ADT Digitaltryck, 127-144.

Piličiauskas, G. and Heron, C., 2015. Aquatic radiocarbon reservoir offsets in the Southeastern Baltic. Radiocarbon, 57 (4), 539-556, https://doi.org/10.2458/azu_rc.57.18447.

Piličiauskas, G., Jankauskas, R., Piličiauskienè, G., Craig, O. E., Charlton and S., Dupras, T., 2017. The transition from foraging to farming $(7000-500 \mathrm{cal} \mathrm{BC})$ in the SE Baltic: A reevaluation of chronological and palaeodietary evidence from human remains. Journal of Archaeological Science: Reports, 14, 530-542, https://doi.org/10.1016/j.jasrep.2017.06.004.

Rimantienè, R., 1996. Akmens amžius Lietuvoje. Vilnius: Žiburio leidykla.

Sørensen, S.A., 2016. Loose human bones from the Danish Mesolithic. In: J.M. Grünberg, B. Gramsch, L. Larsson, J. Orschiedt and $\mathrm{H}$. Meller, eds. Mesolithic burials - rites, symbols and social organisation of early postglacial communities. Halle (Saale), 63-72.

Tõrv, M., 2016. Persistent Practices. A Multi-Disciplinary Study of Hunter-Gatherer Mortuary Remains from c. 6500-2600 cal. BC, Estonia. Dissertationes Archaeologiae Universitatis Tartuensis 5. Tartu: University of Tartu Press.

\section{KRETUONAS: ŽMONIŲ KAULAI \\ SU PJOVIMO ŽYMĖMIS IR \\ JŲ REIKŠMĖ ANKSTYVOJO- VIDURINIO NEOLITO LAIDOJIMO TRADICIJOMS DABARTINEJE LIETUVOS TERITORIJOJE}

\section{MANTAS DAUBARAS}

\section{Santrauka}

Šiame straipsnyje pristatomi nauji bioarcheologiniai atradimai, padaryti iš naujo peržiūrejjus $1980 \mathrm{~m}$. tyrinètų Kretuono 1B gyvenvieteje rastų kapų osteologinę medžiagą. Peržiūrint osteologinę Kretuono 1B kapinyno medžiagą, ji buvo kruopščiai valoma sausuoju būdu ir analizuojama, naudojant mažo didinimo didinamąji stiklą. Iš naujo peržiūrèta ir ištirta bioarcheologinè medžiaga atskleide pirmuosius dabartinès Lietuvos teritorijoje žinomus perimortalinius žmogaus kaulų pjaustymo atvejus. Kape 2 palaidoto 14-16 metų amžiaus nenustatytos lyties individo kairysis žastikaulis bei dešinysis šlaunikaulis turèjo pakar- 
toninių, perimortalinių pjūvių / kirčių žymių, kurios buvo atliktos aštriu, precizišku ịrankiu pjaunant išilgai kaulų išilginès ašies, o vèliau perlaužiant juos skersai.

Žmonių kaulų su pjovimo / kapojimo žymėmis suradimas pats savaime nèra unikalus ar vertas atskiro straipsnio, tačiau tokių atvejų buvimas archeologinejje medžiagoje leidžia kelti klausimus apie vidurinio-vèlyvojo neolito (5500/5300-3100/2900 cal BC) bendruomeniu laidojimo tradicijas. Šiame straipsnyje, remiantis Kretuono $1 \mathrm{~B}$ medžiaga bei europiniu archeologiniu kontekstu, galima teigti, jog dabartinejje Lietuvos teritorijoje viduriniame-vèlyvajame neolite gyvenusios bendruomenès turejo skirtingas laidojimo tradicijas. Ne su visais mirusiaisiais buvo elgiamasi vienodai - dalis jų iki palaidojimo pereidavo skirtingas laidojimo apeigas, kurių metu galejo būti mėsinejjami, atskiriamos tam tikros jų kūno dalys. Tokie atvejai yra nustatyti beveik visuose žinomuose Europos kapinynuose, todèl Kretuono bioarcheologinèje medžiagoje surastas atvejis tik parodo, kad dabartineje Lietuvos teritorijoje gyvenusios bendruomenès buvo bendros europinès medžiotojų-rankiotojų rituališkai turtingos ir ịvairios laidosenos dalis.

Tikètina, kad iš naujo peržiūrèjus ankstesnių tyrinejjimų metu Lietuvoje ir aplinkinėse šalyse rastą akmens amžiaus laidojimo objektų bioarcheologinę medžiagą, bus nustatyta ir daugiau panašių atvejų. 